\title{
The utilization of fermented sago waste as feed source for ettawa crossbreed goat feed
}

\author{
Junaedi Edi $^{* 1)}$ and Irwansyah ${ }^{1)}$ \\ 1) Animal Husbandry Study Program, Faculty of Agriculture, Fisheries and Animal \\ Husbandry, Universitas Sembilanbelas November, Kolaka, Jl. Pemuda No. 339, \\ Kolaka 93517, Indonesia
}

Submitted: 18 June 2019, Accepted: 06 April 2020

\begin{abstract}
This research aims to utilize local feed resources for Ettawa crossbreed (PE) goat by mixing the fermented sago waste (FSW) with forages. In this research, 9 PE goats at the age of 6 months and weighed at $17.46 \pm 0.3 \mathrm{~kg}$ were used as the research subject. The fermented sago waste consisted of $75 \%$ sago waste, $20 \%$ bran, $0.25 \%$ urea, $3 \%$ molasses, and $1.25 \%$ urea. Probion was added as much as $0.5 \%$ of total feed weight. All of the feedstuffs were mixed and fermented in anaerobic conditions for 21 days. The feeding was then divided into three groups, which were: $100 \%$ forage $+0 \% \mathrm{FSW}(\mathrm{A})$; $70 \%$ forage $+30 \% \mathrm{FSW}(\mathrm{B})$; and $50 \%$ forage $+50 \%$ FSW (C). The observed parameters were average daily gain (ADG) and feed conversion ratio (FCR). All of the data were analyzed in a completely randomized design. The analysis showed a significant difference $(\mathrm{P}<0.05)$ on the ADG of $\mathrm{PE}$ goats, with the highest was obtained in $30 \%$ FSW addition $(86.10 \pm 1.90$ grams/goat/day), followed with $50 \%$ FSW addition ( $80 \pm 3.41$ gram/goat/day), while the $100 \%$ forage feeding showed the lowest ADG at $72.14 \pm 3.96$ gram/goat/day). However, there is no significant difference $(\mathrm{P}>0.05)$ to the FCR in all treatments, which showed FCR at 9.68 to 9.98 .
\end{abstract}

Keywords: Sago waste; Fermentation; PE goats

*Corresponding Author: junaedi.peternakan @ gmail.com 


\section{INTRODUCTION}

Goat is one of the common reared livestock in many regions in Indonesia. The preferred goat breed by local farmers is Ettawa crossbreed (PE) due to its productivity. Even though livestock productivity is highly affected by its genetic value, improper feeding such as giving lowquality feed would have resulted in poor productivity. It is noting that feeding plays an essential role to express the genetic potential of the livestock. In general, goat farmers in Indonesia still practiced traditional goat farming systems, in which the given feed was mainly originated from the surrounding local resource and highly dependent on the environment.

Fermentation is one of the feed processing technology which could improve the nutritional value of low-quality feedstuffs, such as sago waste. The application of the technology would prevent poor livestock productivity due to the low nutritional value of the given feed. The technology could also help farmers to provide alternative feed when the resource is limited. It is already well known that forages are abundant during the rainy season, yet highly limited during the dry season. To solve the limited feed resource during the dry season, the utilization of agricultural wastes, such as sago, for livestock feed additive could be done.

Sago waste is a derivative product obtained from sago flour processing. The sago waste could be used as an alternative high energy feed as it contains $76.51 \%$ nitrogen-free extracts. However, the utilization of sago waste as a single feed is not recommended due to its low crude protein content, thus it should be firstly fermented to improve its nutritional value and added with other feedstuffs into a complete feed. Aside to improve the nutritional value, fermentation would also improve its digestibility, palatability, suppress emitted bad odor and relatively safer for the environment. In this research, we aim to determine the optimal formulation of fermented sago waste and forages for PE goat feed.

\section{MATERIALS AND METHODS Materials}

The research subjects were 9 Ettawa crossbreed (PE) goats at the age of 6 months and weighed at $17.46 \pm 0.30 \mathrm{~kg}$. The fermented sago waste (FSW) was made by mixing $75 \%$ sago waste, $20 \%$ bran, $0.25 \%$ urea $3 \%$ molasses, mineral $1.25 \%$ and $0.5 \%$ probion, and then fermented in anaerobic condition for 21 days.

\section{Methods}

The research was done in three months. The PE goats were firstly adapted to the feed treatments for three weeks or until reached stable condition before observed. The data were then collected after the adaptation period, and the composition of feed treatments are as follow:
A $: 100 \%$ forage $+0 \%$ FSW
B : $70 \%$ forage $+30 \%$ FSW
C $: 50 \%$ forage $+50 \%$ FSW

\section{Observed variables}

1. Average daily gain (ADG)

$\mathrm{ADG}=\frac{\text { Final weight-Initial weight }}{\text { Time }}$

2. Feed conversion ratio (FCR) $\mathrm{FCR}=\frac{\text { Total consumed feed }}{\text { Weight gain }}$

\section{Data analysis}

The obtained data were analyzed in a $3 \times 3$ completely randomize design following Steel and Torrie (1991) as follow:

$\mathrm{Yij}=\mu+\pi \mathrm{i}+€ \mathrm{ij}$

Description:

I $\quad=1,2,3$, treatments

$\mathrm{j} \quad=1,2,3$, replications

Yij $=$ Observed treatments at $\mathrm{i}$ and replication at $\mathrm{j}$

$\mu \quad=$ Mean value

$\pi \mathrm{i} \quad=$ Treatments effect at $\mathrm{i}$

$€ \mathrm{ij}=$ Treatments deviation at $\mathrm{I}$ and deviation to $\mathrm{j}$

Any significant differences $(\mathrm{P}<0.05)$ will be followed by Duncan's Multiple Range Test (Kaps and Lamberson, 2004). 


\section{RESULTS AND DISCUSSION}

\section{The effect of FSW to the ADG of PE goats}

The initial weight of PE goats was at 17.32 to $17.58 \mathrm{~kg}$ with an average of 17.46 $\mathrm{kg}$. After reared for two months, the final weight was at $21.62 \mathrm{~kg}$ to $22.31 \mathrm{~kg}$ with an average of $21.91 \mathrm{~kg}$. In this research, the obtained ADG was at $79.41 \pm 6.56$ gram/goat/day. The analysis showed that there is a significant difference $(\mathrm{P}<0.05)$ on the ADG of PE goats after a feed with different percentage FSW addition. The results showed that the highest ADG was shown in PE goats feed with $30 \%$ FSW addition (86.10 \pm 1.90 gram/goat/day), and then followed with $50 \%$ FSW addition (80 \pm 3.41 gram/goat/day) and without FSW addition (72.14 \pm 3.96 gram/goat/day). The different ADG in this study is caused by the fermentation process which increases the feed digestibility and lowers the crude fiber content. However, the high addition of FSW could cause feed toxicity. The ADG of PE goats in this study is measured by reducing the final weight of PE goats with its initial weight and then divided with rearing time and presented in the units of gram/goat/day. The results of ADG and FCR measurement of $\mathrm{PE}$ goats in this study is presented in Table 1 .

Table 1. The mean value of ADG and FCR of PE goats fed with different FSW percentage

\begin{tabular}{lcccc}
\hline Parameters & $0 \%$ FSW & $30 \%$ FSW & $50 \%$ FSW & Mean \\
\hline Initial weight (kg) & 17.58 & 17.49 & 17.32 & 17.46 \\
Final weight (kg) & 21.62 & 22.31 & 21.80 & 21.91 \\
ADG (gram/goat/ day) & $72.14 \pm 3.96^{\mathrm{a}}$ & $86.10 \pm 1.90^{\mathrm{b}}$ & $80 \pm 3.41^{\mathrm{c}}$ & $79.41 \pm 6.56$ \\
FCR & $9.69 \pm 0.48$ & $9.98 \pm 0.21$ & $9.68 \pm 0.38$ & $9.78 \pm 0.39$ \\
\hline
\end{tabular}

The ADG of PE goats fed with FSW addition was higher compared to without FSW addition. It is caused by the proteolytic, ligninolytic, cellulolytic, and lipolytic bacteria contained in the FSW, which are responsible for degrading crude fibers in feed and resulted in better feed digestibility and weight gain. The cellulolytic enzyme works in complex reactions that cleave the cellulose into oligosaccharides (Lin et al., 2012). Perry, Cullison, and Lowrey (2003) explained that the high crude fibers in feed would inhibit its feed digestibility. Research by Ratnakomala, Ridwan, Kartina, and Widyastuti (2006) showed that the lactic acid bacteria in the fermented feed could improve the livestock ADG as well.

The feed efficiency can be determined by measuring the feed conversion ratio (FCR). The FCR has indicated how the consumed feed is utilized for body growth, with lower FCR showed better feed efficiency. The mean FCR in this study is presented in Table 1. In this study, it is shown that different FSW addition did not give a significant difference $(\mathrm{P}>0.05)$ to the
FCR of PE goats, with the obtained FCR is at 9.68 to 9.98 . The results showed that it required 9.68 to $9.98 \mathrm{~kg}$ of feed to increase $1 \mathrm{~kg}$ body weight of PE goats. The obtained FCR in this study is higher compared to research by Ginting (2014) which showed FCR at 6.38 to 8.02. Research by Suparjo, Wiryawan, Laconi, and Mangunwidjaja (2011) also showed better FCR (6.77) of goats fed with $50 \%$ fermented KBK, $20 \%$ concentrates and $30 \%$ Napier grass. However, the obtained FCR in this research is better compared to the finding by Suparman, Hafid, and Baa (2016) which combined local feed resources (mulberry, gliricidia, and tamarind leaves) on PE goats and obtained 10.83 to 12.36 FCR.

The improvement of feed quality should be done to optimize the utilization of agricultural waste as livestock feed. The sago waste was produced during sago flour production, and the direct utilization of sago waste resulted in inefficient feed consumption due to its high crude fiber contents. Laesari and Purwadaria (2004) described that feed fermentation would improve feed quality by producing simpler 
substances to be digested by the livestock. During fermentation, the metabolism of fermenting microorganisms would breakdown complex substance and produced simpler products with a unique aroma.

The produced unique aroma would improve its palatability as well. Besides, the crude fibers contained in feed would also be degraded by the cellulolytic microorganism during fermentation. Fermentation could also improve the feed shelf-life by lactic acid production of the microorganism. The produced lactic acid would lower feed $\mathrm{pH}$ and inhibit the growth of the pathogens (McDonald, Henderson, and Heron 1981). Research by Wulandari et al. (2014) showed that aside from breaking down the crude fibers, cellulolytic and amylolytic bacteria would accelerate the $\mathrm{pH}$ reduction by producing organic acids. Saha, Sana, and Shaha (2016) explained that organic matters is consisted of carbohydrates, proteins, and fats, and can provide energy when consumed.

The measurement of organic matter digestibility can be used to determine feed quality (Dinata, Widiyanto, dan Pujianingsih 2015). Ohmomo, Nitisinprasart, and Hiranpradit (2002) described that the recommended fermentation in Japan is done at 60 to $65 \%$ moisture. The mixing of sago waste with bran in this study was aimed to reduce the moisture and ensure successful fermentation.

\section{CONCLUSION}

The different FSW addition showed significant difference to the ADG of PE goats, with the highest is obtained when fed with $30 \%$ FSW addition (86.10 \pm 1.90 gram/goat/day), followed with $50 \%$ FSW addition (80 \pm 3.41 gram/goat/day), while the lowest was obtained without FSW addition (72.14 \pm 3.96 gram/goat/day). The different FSW addition did not give significant effect $(\mathrm{P}>0.05)$ to the FCR, with the obtained FCR of PE goats fed was 9.68 to 9.98 .

\section{ACKNOWLEDGMENTS}

We would like to thank the Directorate of Research and Community Service, Directorate General of Research Empowerment and Development, Ministry of Research, Technology and Higher Education for the research fund through the Penelitian Dosen Pemula (PDP) program. We would also like to thank the Rector of Universitas Sembilanbelas November Kolaka and LPPM USN Kolaka for their supports and contributions in this research. Special thanks to Redi for his help during the field research.

\section{REFERENCES}

Dinata, D. D., Widiyanto, W., \& Pujaningsih, R. I. (2015). Pengaruh suplementasi dan proteksi minyak biji kapuk terhadap fermentabilitas ruminal rumput gajah pada sapi secara in vitro. Jurnal Agripet, 15(1), 46-51. https:// doi.org/10.17969/agripet.v15i1.2299

Ginting, S. P., Tarigan, A., Hutasoit, R., \& Yulistiani, D. (2015). Preferences, digestibility and rumen fermentation characteristics of several mulberry species in goats. Jurnal Ilmu Ternak Dan Veteriner, 19(3), 176-183. https:// doi.org/10.14334/jitv.v19i3.1080

Kaps, M., \& Lamberson, W. R. (2004). Biostatistic of Animal Science. Cambridge: Cabi Publishing.

Lin, L., Kan, X., Yan, H., \& Wang, D. (2012). Characterization of extracellular cellulose-degrading enzymes from Bacillus thuringiensis strains. Electronic Journal of Biotechnology, 15(3), 1-7. https://doi. org/10.2225/vol15-issue3-fulltext-1

Mc Donald, P., Henderson, A. R., \& Heron, S. J. E. (1981). The Biochemistry of Silage (6th ed.). Canterbury UK: Chalcombe Publication.

National Research Council. (1981). Nutrient Requirement of Goats: Angora, Dairy, and Meatgoats in Temperate and Tropical Countries. Washington DC: National Academy Press. 
Ohmomo, S., Nitisinprasart, S., \& Hiranpradit, S. (2002). Silage-making and recent trend of dairy farming in Thailand. Japan Agricultural Research Quarterly: JARQ, 36(4), 227-234. https://doi.org/10.6090/jarq.36.227

Perry, T. W., Cullison, A. E., \& Lowrey, R. S. (2003). Feed \& Feeding (6th ed.). Upper Saddle River New Jersey: Pearson Edication, Inc.

Ratnakomala, S., Ridwan, R., Kartina, G., \& Widyastuti, Y. (2006). The effect of Lactobacillus plantarum $1 \mathrm{~A}-2$ and 1BL-2 inoculant on the quality of napier grass silage. Biodiversitas, Journal of Biological Diversity, 7(2), 131-134. https://doi.org/10.13057/bio $\mathrm{div} / \mathrm{d} 070208$

Saha, M., Sana, N., \& Shaha, R. K. (1970). Serum lipid profile of hypertensive patients in the northern region of Bangladesh. Journal of Bio-Science, 14, 93-98. https://doi.org/10.3329/jbs. v14i0.450

SARI, L., \& Purwadaria, T. (2004). Evaluate the effect of mutans Aspergillus niger to the nutritive value of fermentation at coconut meal and karnel palm meal. Biodiversitas, Journal of Biological Diversity, 5(2), 48-51. https://doi.org/ 10.13057/biodiv/d050202
Steel, R. G., \& Torrie, J. H. (1991). Prinsip dan Prosedur Statistika. In B. Sumantri (Ed.), Suatu Pendekatan Biometrik (2nd ed.). Jakarta: Gramedia.

Suparjo, S., Wiryawan, K. G., Laconi, E. B., \& Mangunwidjaja, D. (2011). Performa kambing yang diberi kulit buah kakao terfermentasi. Media Peternakan, 34(1), 35-41. https://doi. org/10.5398/medpet.2011.34.1.35

Suparman, S., Hafid, H., \& Ode Baa, L. (2016). Kajian pertumbuhan dan produksi kambing peranakan ettawa jantan yang diberi pakan berbeda. JITRO, 3(3), 1-9. https://doi.org/10. 33772/JITRO.V3I3.1842

Wulandari, S., Agus, A., Soejono, M., Cahyanto, M. N., \& Utomo, R. (2014). Performa produksi domba yang diberi complete feed fermentasi berbasis pod kakao serta nilai nutrien tercernanya secara in vivo. Buletin Peternakan, 38(1), 42. https://doi.org/10.21059/ buletinpeternak.v38i1.4615 